\title{
Hubungan Paritas Dengan Tingkat Kecemasan Ibu Menghadapi Persalinan Normal
}

\author{
The Relationship between Parity and the Anxiety Level of Mother Facing \\ Normal Delivery
}

\author{
Sinta Ayu Setiawan', Lania Nur Faiza ${ }^{2}$ \\ Akbid Harapan Mulya Ponorogo ${ }^{1}$ \\ STIKES Hafshawaty Zainul Haasan Genggong Probolinggo \\ Email $^{1}$ : sinta.generous42@gmail.com
}

\begin{abstract}
ABSTRAK
Semua jenis persalinan akan menyebabkan kecemasan pada ibu bersalin terutama bila persalinan itu merupakan yang pertama. Tujuan penelitian ini untuk menganalisa hubungan paritas dengan tingkat kecemasan ibu menghadapi persalinan normal di Praktek Mandiri Bidan (PMB) Ny. Sutami Desa Gabel Kecamatan Kauman Kabupaten Ponorogo.Jenis penelitian ini adalah analitik korelasional dengan rancangan penelitian cross sectional. Penelitian dilakukan pada Bulan Mei sampai dengan Juni 2018. Sampel diambil menggunakan total sampling. Data penelitian dikumpulkan dengan menggunakan kuesioner dan cheklis skala HARS. Data yang terkumpul kemudian ditabulasi, dianalisa univariate, dan analisa bivariate menggunakan uji statistik Spearman Rank dengan bantuan program SPSS 18,0. Hasil penelitian menunjukkan 22 ibu (55\%) adalah primipara (baru pertama melahirkan), dan 15 responden $(37,5 \%)$ memiliki tingkat kecemasan ringan. Berdasarkan hasil uji statistic Spearman Rank menunjukkan nilai Sig (2-tailed) adalah 0,009 (nilai $\rho 0,009<\alpha 0,05$ ) yang berarti $\mathrm{H}_{0}$ ditolak ada hubungan paritas dengan tingkat kecemasan menghadapi persalinan.
\end{abstract}

Kata Kunci : Paritas, Kecemasan, Persalinan.

\begin{abstract}
Many type of childbirth will cause anxiety to the mother, especially if it is the first time.The purpose of this study was to analyze the relationship of parity with the level of anxiety of mothers facing normal childbirth in Independent Midwife Practice (PMB) Ny. Sutami Gabel Village, Kauman District, Ponorogo Regency. This type of research is correlational analysis with cross sectional research design. The research was conducted in PMB Ny. Sutami Gabel Village, Kauman District, Ponorogo Regency, May to June 2018. Samples were taken using total sampling. Research data was collected using a questionnaire and the HARS scale cheklis. The collected data was then tabulated, univariate analyzed, and bivariate analysis using Spearman Rank statistical test with the help of SPSS 18.0 program. The results showed that 22 mothers $(55 \%)$ were primipara (first giving birth), and 15 respondents $(37.5 \%)$ had mild anxiety levels. Based on the results, the Sig (2-tailed) value is 0.009 (value $\rho 0.009<\alpha 0.05)$, which means that $H_{0}$ is rejected there is a relationship between parity with the level of anxiety facing childbirth.
\end{abstract}

Keywords: Parity, Anxiety, Childbirth.

\section{PENDAHULUAN}

Proses dimana janin dan plasenta

keluar dari rahim, ditandai dengan

peningkatan frekuensi dan lama

kontraksi yang menyebabkan perubahan serviks serta pengeluaran vagina berupa lendir bercampur darah (show) disebut persalinan (Prawirohardjo, 2014). Proses persalinan seringkali menyebabkan 
kecemasan terutama pada persalinan pertama.

Kecemasan merupakan kondisi fisik dan psikologis yang ditandai adanya komponen somatik, emosi, kognitif, dan perilaku sebagai reaksi normal dari stres. Kecemasan bisa menghasilkan perasaan takut, khawatir, gelisah (Sue, 2014). Kemampuan seorang wanita sehubungan dengan jumlah persalinan dan jumlah anak yang masih hidup disebut paritas (Dorland, 2016).

Faktor psikis seperti kecemasan belum menjadi masalah yang banyak dikhawatirkan karena petugas kesehatan lebih memperhatikan tanda-tanda somatis. Petugas kesehatan dan keluarga merasa puas apabila bayi sudah lahir dengan selamat dan ibunya tidak menunjukkan tanda abnormal/komplikasi (Manuaba, 2010).

Menurut data WHO, mayoritas kematian ibu akibat persalinan patologi dan harus melahirkan di rumah sakit, banyak terjadi di negara berkembang, sehingga menyebabkan kecemasan pada ibu hamil. Paradigma masyarakat tentang persalinan merupakan peristiwa yang mengancam jiwa membuat wanita mengalami ketakutan akan kematian pada saat proses melahirkan (Manuaba, 2010).

Menurut data jumlah kematian 5000 orang per tahun, pada 2016 jumlah menjadi 4.912, meskipun terjadi penurunan, secara survei angka kematian ibu karena melahirkan masih tetap tinggi. Target Rencana Pembangunan Jangka Menengah Indonesia tahun 20142019 adalah penurunan jumlah AKI menjadi 276 per 100.000 kelahiran (Kemenkes RI, 2017).

AKI Jawa Timur tahun 2016 mengalami peningkatan yaitu 91 dibandingkan 100.000 kelahiran hidup (Dinas Kesehatan Jatim, 2017). Sama halnya dengan AKI Kabupaten Ponorogo juga mengalami peningkatan di tahun 2016 yaitu sebesar 112 dibandingkan 100.000 kelahiran hidup (12 ibu meninggal). AKI di Kabupaten Ponorogo menempati peringkat 12 dari seluruh Kabupaten di Jawa Timur (Dinkes Ponorogo, 2017).

Berdasarkan buku register bidan Sutami pada tahun 2017, jumlah persalinan normal 68 orang, dan 22 orang dengan rujukan diantaranya dengan masalah 5 orang (22,7\%) dengan KPD, 7 orang $(31,8 \%)$ dengan kala 1 lama, 3 orang $(13,6 \%)$ dengan letak sungsang, 2 orang $(9,1 \%)$ dengan CPD, 
3 orang $(13,6 \%)$ dengan PEB, 1 orang (4,5\%) dengan APB, dan 1 (4,5\%) orang dengan PRM. Hasil wawancara yang dilakukan pada 10 orang ibu hamil Trimester ketiga didapatkan 6 orang $(60 \%)$ mengatakan cemas menjelang proses persalinannya dengan alasan belum pernah melahirkan dan sebagian menyatakan khawatir dengan keadaan bayinya, dan 4 orang (40\%) mengatakan tidak cemas menjelang proses persalinannya dengan alasan sudah pernah melahirkan.

Notoadmodjo (2013) yang menyatakan pengetahuan dipengaruhi oleh faktor eksternal, pendidikan formal atau non formal, informasi dan pengalaman. Dengan demikian semakin sering melahirkan maka seseorang lebih banyak pengalaman, sehingga mempengaruhi tingkat kecemasan ibu bersalin. Perasaan cemas dan ketakutan menghadapi proses persalinan, ketegangan jiwa yang dibawa sampai proses persalinan, menimbulkan lingkaran fear tension pain yang akan mengakibatkan penyulit pada proses persalinan. Pernyataan tersebut menyiratkan bahwa kecemasan persalinan merupakan faktor yang sangat mempengaruhi kelancaran proses kelahiran. Dukungan moril yang penuh dari anggota keluarga dan petugas kesehatan sangat penting artinya bagi Ibu bersalin dalam menghadapi kecemasan (Manuaba, 2010).

\section{METODE PENELITIAN}

Penelitian ini menggunakan pendekatan analitik korelasional dengan rancangan cross sectional. Besar sampel pada bulan Mei - Juni 2018 sejumlah 40 ibu bersalin yang diambil menggunakan teknik total sampling. Instrumen variabel paritas menggunakan kuesioner, sedangkan pada tingkat kecemasan menggunakan cheklist dari skala HARS.

Pengolahan data variabel Paritas dibedakan : 1) Primipara: Paritas 1,2) Multipara : Paritas 2-4, 3) Grandemultipara : Paritas > 4, sedangkan untuk variabel tingkat kecemasan dibedakan sebagai berikut :1) Tidak ada gejala sama sekali $=0$, 2) Satu gejala dari pilihan yang ada $=1$, 3) Separuh dari gejala yang ada $=2,4$ ) Lebih dari separuh dari gejala yang ada $=3,5)$ Semua gejala ada $=4$ Setelah diketahui, kemudian hasilnya dikategorikan pada kriteria: 1) Score $<6$ = tidak ada kecemasan, 2) Score 6-14 = kecemasan ringan, 3) Score 15-27 = kecemasan sedang, 4) Score $>27=$ kecemasan berat. 
Analisa bivariate menggunakan uji statistik Spearman's rank pada taraf signifikasi 0,05. Jika $\rho<\alpha 0,05 \mathrm{H}_{0}$ ditolak dan jika $\rho>\alpha 0,05$ maka $\mathrm{H}_{0}$ di terima (Sugiyono, 2012).

\section{HASIL DAN PEMBAHASAN}

\section{Paritas}

\section{Tabel 1. Distribusi Frekuensi Paritas} Ibu Bersalin

\begin{tabular}{lcc}
\hline Paritas & Frekuensi & $\begin{array}{c}\text { Prosentase } \\
(\mathbf{\%})\end{array}$ \\
\hline Primipara & 25 & 62,5 \\
Multipara & 13 & 32,5 \\
Grande- & 2 & 5,0 \\
multipara & & \\
\hline Total & $\mathbf{4 0}$ & $\mathbf{1 0 0}$ \\
\hline \multicolumn{2}{c}{ Berdasarkan } & tabel
\end{tabular}

menunjukkan 25 responden $(62,5 \%)$ adalah primipara (baru pertama melahirkan), dan 2 reponden (5\%) adalah grandemultipara (melahirkan > 4 kali).

Paritas menurut Friedman (2016) dipengaruhi oleh pendidikan dan pekerjaan. Berdasarkan hasil penelitian setengah dari responden 20 ibu (50\%) mempunyai pendidikan menengah. Pendidikan tinggi membuat seseorang semakin mudah dalam menerima informasi atau edukasi, sehingga akan berpikir lebih rasional. Ibu yang mempunyai pendidikan tinggi cenderung menganggap jumlah anak yang ideal adalah 2 orang.
Jembatan untuk menghasilkan materi dalam rangka memenuhi semua kebutuhan hidup untuk keluarga disebut pekerjaan (Friedman, 2016).

Pendapat bahwa jenis pekerjaan menentukan jumlah anak didasarkan atas kemampuan memberi nafkah anak sesuai dengan hasil penelitian yang menunjukkan dari seluruh responden yang berjumlah 40 ibu, 8 ibu (20\%) memiliki pekerjaan swasta, $7 \mathrm{ibu}(17,5 \%)$ bekerja sebagai petani, dan 2 ibu (5\%) bekerja sebagai pegawai negeri sipil.

Pilihan dalam menentukan berapa jumlah anak dipengaruhi oleh pendidikan dan pekerjaan, tetapi banyak terjadi ibu yang memiliki pendidikan rendah dan tidak bekerja memiliki banyak anak (lebih dari 2) karena tidak mengikuti program KB, ada juga yang berpendapat banyak anak berarti banyak rejeki.

\section{Kecemasan}

Tabel 2. Distribusi Frekuensi Kecemasan Ibu Bersalin

\begin{tabular}{|c|c|c|}
\hline $\begin{array}{l}\text { Tingkat } \\
\text { Kecemasan }\end{array}$ & Frekuensi & $\begin{array}{c}\text { Prosentase } \\
(\%)\end{array}$ \\
\hline Tidak Ada & 3 & 7,5 \\
\hline Kecemasan & & \\
\hline Ringan & 11 & 27,5 \\
\hline Sedang & 15 & 37,5 \\
\hline Berat & 11 & 27,5 \\
\hline Total & 40 & 100 \\
\hline
\end{tabular}

menunjukkan 15 responden $(37,5 \%)$ memiliki tingkat kecemasan sedang, 
dan 3 responden $(7,5 \%)$ tidak ada kecemasan.

Hal tersebut dapat disebabkan karena 29 responden $(72,5 \%)$ berumur 20-35 tahun, sehingga dengan umur yang masih tergolong menengah masih memungkinkan memiliki kecemasan berat menjelang proses persalinan, karena tingkat kecemasan dipengaruhi oleh umur. Hasil penelitian ini sesuai dengan pendapat Prawirohardjo (2010), yang membagi umur kedalam tiga kategori, yaitu: kurang dari 20 tahun termasuk usia muda, 20-30 tahun tergolong usia menengah, dan lebih dari 30 tahun adalah usia tua. Stuart (2013) menyatakan usia yang lebih muda akan lebih cepat stress.

Kecemasan adalah respon yang dapat dipelajari. Pendidikan yang rendah menjadi faktor penunjang terjadinya kecemasan. 3 responden $(7,5 \%)$ tidak ada kecemasan, hal tersebut dapat disebabkan oleh pendidikan ibu yang tinggi yaitu 6 ibu (15\%) berpendidikan tinggi. Stuart (2013) mengatakan bahwa pengetahuan yang rendah mengakibatkan seseorang mudah mengalami stress, pendapat ini menegaskan hasil penelitian di atas.
Kecemasan dalam proses persalinan adalah hal yang normal karena persalinan adalah proses menengangkan antara hidup dan mati, namun kecemasan berlebihan dapat dicegah dengan dukungan keluarga dan bidan sehingga sangat dianjurkan ibu yang bersalin normal harus didampingi keluarga di ruang bersalin.

\section{Hubungan Paritas dengan}

\section{Kecemasan}

Tabel 3. Hasil Uji Statistik Spearman

\begin{tabular}{|c|c|c|c|c|}
\hline & & & $\begin{array}{l}\text { Paritas } \\
\text { Ibu } \\
\text { Bersalin }\end{array}$ & $\begin{array}{c}\text { Kecemasan } \\
\text { Ibu } \\
\text { Bersalin }\end{array}$ \\
\hline \multirow{6}{*}{$\begin{array}{l}\text { Spear } \\
\text { man's } \\
\text { rho }\end{array}$} & $\begin{array}{l}\text { Paritas } \\
\text { Ibu }\end{array}$ & $\begin{array}{l}\text { Correlation } \\
\text { Coefficient }\end{array}$ & 1.000 & $-.408^{* *}$ \\
\hline & Bersalin & $\begin{array}{l}\text { Sig. (2- } \\
\text { tailed) }\end{array}$ & . & .009 \\
\hline & & $\mathrm{N}$ & 40 & 40 \\
\hline & $\begin{array}{l}\text { Kecema } \\
\text { san Ibu }\end{array}$ & $\begin{array}{l}\text { Correlation } \\
\text { Coefficient }\end{array}$ & $-.408^{* *}$ & 1.000 \\
\hline & Bersalin & $\begin{array}{l}\text { Sig. }(2- \\
\text { tailed) }\end{array}$ & .009 & \\
\hline & & $\mathrm{N}$ & 40 & 40 \\
\hline
\end{tabular}

Berdasarkan hasil analisa nilai Sig (2-tailed) adalah 0,009 (nilai $\rho$ $0,009<\alpha 0,05)$ yang berarti $\mathrm{H}_{0}$ ditolak artinya ada hubungan paritas dengan tingkat kecemasan dengan tingkat keeratan hubungan sedang bisa dilihat dari Correlation Coefficient -0,408, tanda negatif (-) dapat diartikan semakin sering melahirkan maka tingkat kecemasan semakin menurun. 
Hamilton (2016) mengatakan bahwa pengetahuan yang rendah terhadap sesuatu membuat tekanan yang mengakibatkan krisis dan menimbulkan kecemasan. Individu yang kurang informasi tentang sesuatu mengakibatkan stress. Sehingga dari pengetahuan tersebut merupakan suatu cara untuk memperoleh kebenaran pengetahuan, baik dari pengalaman diri sendiri maupun orang lain. Pengalaman yang diperoleh pada persalinan sebelumnya dapat digunakan dalam mengatasi masalah yang dihadapi. Bila berhasil maka orang akan menggunakan cara tersebut dan bila gagal tidak akan mengulangi cara itu. Oleh karena itu semakin semakin tinggi paritas maka kecemasannya semakin menurun.

Hasil penelitian ini didukung oleh penelitian Indrayani (2011) yang menyatakan ada hubungan sangat kuat antara paritas terhadap tingkat kecemasan menghadapi proses persalinan dengan signifikan $0.000<a$ 0,05 dan coefficient correlation sebesar 0.891 .

\footnotetext{
Kecemasan menghadapi proses persalinan disebabkan oleh berbagai faktor yang saling berkaitan
}

yaitu umur, pendidikan, paritas dan dukungan. Ibu yang hamil pada usia matang dan memiliki pendidikan tinggi bisa mengalami kecemasan yang berat karena belum ada pengalaman dalam proses persalinan ditambah dengan ketidakhadiran keluarga saat proses persalinan.

\section{SIMPULAN DAN SARAN}

Dari hasil penelitian tersebut dapat disimpulkan bahwa 22 ibu (55\%) primipara (baru pertama melahirkan), 15 ibu $(37,5 \%)$ memiliki tingkat kecemasan ringan. Ada hubungan paritas dengan tingkat kecemasan menghadapi persalinan normal Di PMB Ny. Sutami di Desa Gabel Kecamatan Kauman Kabupaten Ponorogo dengan nilai Asymp. Sig. (2 tailed)) 0,009 < 0,05 dan Correlation Coefficient -0,408 yang menunjukkan tingkat hubungan sedang.

\section{DAFTAR PUSTAKA}

Arikunto, S. 2010. Prosedur Penelitian Suatu Pendekatan Praktek. Jakarta : Raneka Cipta.

Bobak, Lowdermilk, Jensen. 2012. Buku Ajar Keperawatan Maternitas. Jakarta: EGC 
Carpernito, LJM. 2013. Buku Saku Diagnosis Keperawatan Edisi 13. Jakarta: EGC

Dendy, S. 2008. Kamus Besar Bahasa Indonesia Pusat Bahasa Edisi Keempat. Jakarta: PT Gramedia Pustaka Utama

Dorland. 2016. Kamus Saku Kedokteran Dorland Edisi 28. Jakarta: EGC

Friedman, M.M. 2016. Buku Ajar Keperawatan Keluarga: Riset Teori \& Praktik Edisi 5. Jakarta: EGC

Gunarsa Singgih. 2008. Psikologi Perawatan. Jakarta : BPK-GM

Hamilton, P.M. 2016. Dasar-Dasar Keperawatan Maternitas Edisi 6 (REVISI). Jakarta : EGC

James, Steer, Wener, Gonik, Crowther, Robson. 2010. High Risk Pregnancy: Management Options 4th Edition . Saunders

Lestari, Titik. 2015. Kumpulan Teori Untuk Kajian Pustaka Penelitian Kesehatan. Yogyakarta: Nuha Medika

Manuaba, I. 2010. Ilmu Kebidanan, Penyakit Kandungan dan Keluarga Berencana Untuk Pendidikan Bidan. Jakarta: EGC

Notoatmodjo. 2013. Notoatmodjo, Soekidjo. 2012. Metodologi
Penelitian Kesehatan. Jakarta:Rineka Cipta

Nursalam. 2013. Metode Penelitian Ilmu Keperawatan. Salemba Medika, Jakarta.

Prawirohardjo, S. 2010. Panduan Praktis Pelayanan Kesehatan Maternal dan Neonatal. Jakarta: Yayasan Bina Pustaka Sarwono Prawihardjo.

Rufaidah, Elina Rharisti. 2009. Efektifitas Terapi Kognitif terhadap Penurunan. Tingkat Kecemasan pada Penderita Asma di Surakarta. Tesis. Fakultas. Psikologi-UGM.

Saifudin, A. B. 2011. Buku Acuan Nasional Pelayanan Kesehatan Maternal dan Neonatal. Yayasan Bidan Pustaka.

Santoso. (2009). Peran Wanita Dalam Menciptakan Ketahanan Keluarga. hhtp //prov.bkkbn.go.id Diakses 25 April 2012, Jam 15:40WIB

Santrock, J.W. 2013. Psikologi Pendidikan (Educational Psychology) 1, Edisi 5. Jakarta; Erlangga

Stuart G.W. 2013. Buku Saku Keperawatan Jiwa (Edisi 5). Jakarta: EGC 
Sugiyono. 2012. Statistika untuk

Penelitian. Jakarta: Alfabeta

Wiramihardja, S.A. 2009. Pengantar

Psikologi Klinis (Edisi Revisi).

Yogyakarta: Refika Aditama

Zuyina Lukluk A., Siti Bandiyah. 2011.

Psikologi Kesehatan.

Yogyakarta: Nuha Medika 